\title{
Excessive brain iron accumulation in spinocerebellar ataxia type 17
}

Figure $\quad$ MRI in spinocerebellar ataxia type 17
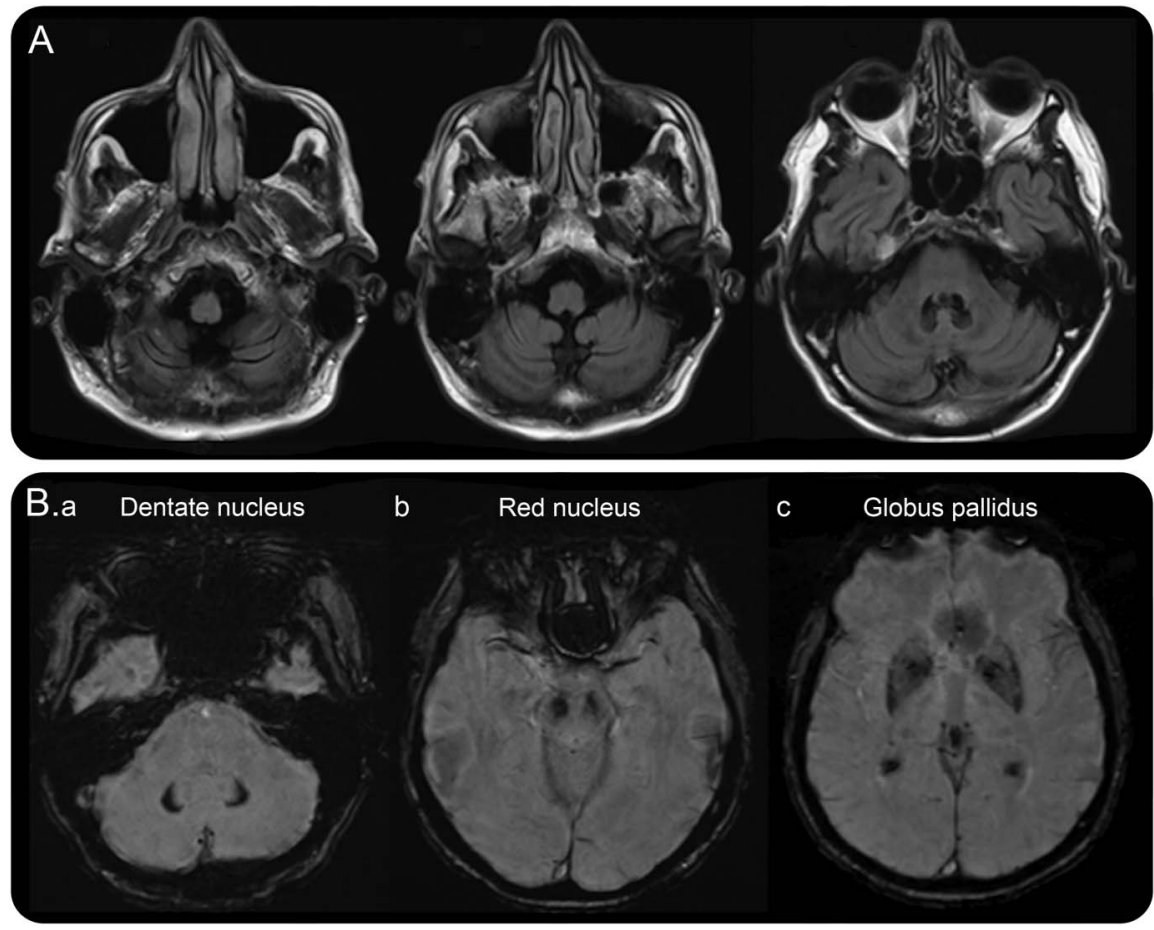

(A) T1-weighted MRI shows cerebellar atrophy. (B) Susceptibility-weighted imaging shows hypointensities in (a) dentate nucleus, (b) red nucleus, and (c) globus pallidus.

A 60-year-old man had a 3-year history of cerebellar ataxia and dementia, without a family history. T1-weighted MRI showed cerebellar atrophy (figure, A). Susceptibility-weighted images (SWI) revealed hypointensities of the basal ganglia and mesencephalic and cerebellar nuclei (figure, $\mathrm{B}, \mathrm{a}-\mathrm{c}$ ), suggesting neurodegeneration with brain iron accumulation. ${ }^{1}$ Serum copper, iron, ferritin, transferrin, and ceruloplasmin levels were normal. Genetic testing revealed a CAG/CAA repeat expansion of 1 allele with 44 repeats (normal range $25-42$ ), within the reduced penetrance range (43-48 repeats) in the TATA box binding protein (TBP) gene. ${ }^{2}$ In patients with cerebellar atrophy with hypointensities of subcortical and cerebellar nuclei in SWI or gradient echo imaging, diagnostic considerations should include spinocerebellar ataxia 17.

Jens Claassen, MD, Wanda Maria Gerding, PhD, Oliver Kastrup, MD, Ellen Uslar, MD, Sophia Goericke, MD, Dagmar Timmann, $M D$

From the University of Duisburg-Essen (J.C., O.K., E.U., S.G., D.T.), Hufelandstr, Essen; and the Institute of Human Genetics (W.M.G.), Ruhr University Bochum, Universitätsstr, Bochum, Germany.

Author contributions: Jens Claassen: drafting/revising the manuscript for content, including medical writing for content and preparation of the figure. Wanda Gerding: drafting/revising the manuscript for content; genetic testing, analysis, and interpretation. Oliver Kastrup: drafting/revising the manuscript for content, including medical writing for content. Ellen Uslar: drafting/revising the manuscript for content. Sophia Goericke: drafting/revising the manuscript for content and interpretation of MRI. Dagmar Timmann: drafting/ revising the manuscript for content, including medical writing for content.

Study funding: No targeted funding reported.

Disclosure: J. Claassen reports no disclosures relevant to the manuscript. W. Gerding received 11/2013-11/2014 FORUM grant F7892013 (principal investigator). O. Kastrup, E. Uslar, and S. Goericke report no disclosures relevant to the manuscript. D. Timmann 
received research support from the German Research Foundation (DFG TI 239/10-1; 10-2), the European Union (Partner in one of the Marie Curie Initial Training Networks), the Bernd Fink Foundation, and the German Heredoataxia Foundation. Go to Neurology.org for full disclosures.

Correspondence to Dr. Claassen: jens.claassen@googlemail.com

1. Schneider SA, Dusek P, Hardy J, Westenberger A, Jankovic J, Bhatia KP. Genetics and pathophysiology of neurodegeneration with brain iron accumulation (NBIA). Curr Neuropharmacol 2013;11:59-79.

2. Koide R, Kobayashi S, Shimohata T, et al. A neurological disease caused by an expanded CAG trinucleotide repeat in the TATA-binding protein gene: a new polyglutamine disease? Hum Mol Genet 1999;8:2047-2053.

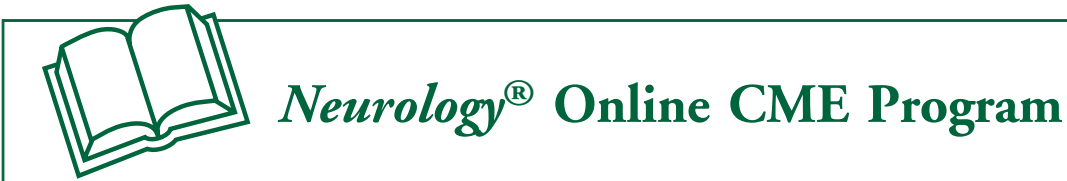

Earn CME while reading Neurology. This program is available only to online Neurology subscribers. Simply read the articles marked CME, go to Neurology.org, and click on CME. This will provide all of the information necessary to get started. The American Academy of Neurology (AAN) is accredited by the Accreditation Council for Continuing Medical Education (ACCME) to sponsor continuing medical education for physicians. Neurology is planned and produced in accordance with the ACCME Essentials. For more information, contact AAN Member Services at 800-879-1960.

\section{It's Time to Plan for ICD-10, and the AAN Can Help}

All health care providers are required to transition to ICD-10 on October 1, 2015. Claims for services performed on or after this date with an ICD-9 code will not be processed and payments will be delayed. The AAN provides information and resources to help you make this a smooth transition, and has partnered with Complete Practice Resources to provide you with an affordable online project management tool to help walk you through each phase of the necessary preparation to ensure you're ready. Learn more at $A A N$.com/view/ICD10 and start your transition today!

\section{AAN Annual Meeting Registration Now Open!}

Registration is now open for the upcoming AAN Annual Meeting, coming to Washington, DC, April 18-25, 2015. Register early to save with deep discounts to the world's largest gathering of neurologists featuring breakthrough scientific research, premier education programming, and unparalleled networking opportunities.

- Hotel Reservation Deadline: March 18, 2015

- Early Registration Discount Deadline: March 27, 2015

Visit AAN.com/view/AM15 today! 


\section{Neurology}

\section{Excessive brain iron accumulation in spinocerebellar ataxia type $\mathbf{1 7}$ Jens Claassen, Wanda Maria Gerding, Oliver Kastrup, et al. Neurology 2015;84;212-213 \\ DOI 10.1212/WNL.0000000000001141}

This information is current as of January 12, 2015

\section{Updated Information \& Services}

\section{References}

Subspecialty Collections

\section{Permissions \& Licensing}

\section{Reprints}

including high resolution figures, can be found at: http://n.neurology.org/content/84/2/212.full

This article cites 2 articles, 0 of which you can access for free at: http://n.neurology.org/content/84/2/212.full\#ref-list-1

This article, along with others on similar topics, appears in the following collection(s):

All Clinical Neurology

http://n.neurology.org/cgi/collection/all_clinical_neurology MRI

http://n.neurology.org/cgi/collection/mri

Spinocerebellar ataxia

http://n.neurology.org/cgi/collection/spinocerebellar_ataxia

Information about reproducing this article in parts (figures,tables) or in its entirety can be found online at:

http://www.neurology.org/about/about_the_journal\#permissions

Information about ordering reprints can be found online:

http://n.neurology.org/subscribers/advertise

Neurology ${ }^{\circledR}$ is the official journal of the American Academy of Neurology. Published continuously since 1951 , it is now a weekly with 48 issues per year. Copyright @ 2015 American Academy of Neurology. All rights reserved. Print ISSN: 0028-3878. Online ISSN: 1526-632X.

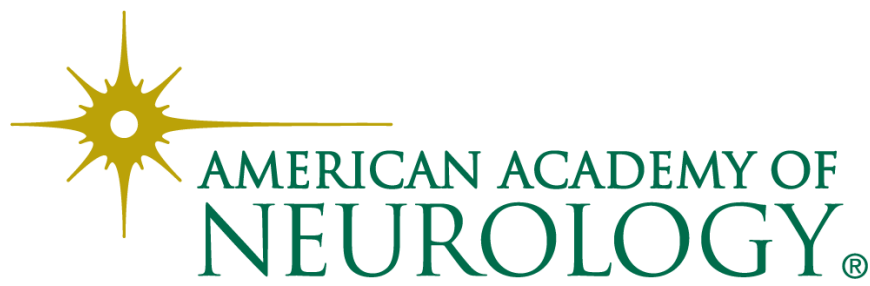

